\title{
Relationship between river bank stability and hydrological processes using in situ measurement data
}

\author{
Gyula Mentes* \\ Geodetic and Geophysical Institute, Research Centre for Astronomy and Earth Sciences, Hungarian \\ Academy of Sciences, Sopron, Hungary
}

Received: July 18, 2018; accepted: December 10, 2018

Many river banks throughout the world are prone to landslides; therefore, serious efforts are made to develop landslide early warning systems. This study presents a method by which the stability changes of the river banks can be continuously monitored; necessary measures can be taken in time to reduce the damage. The method was tested in Dunaszekcsö (Hungary), where the high loess bank of the River Danube has been intensively moving since 2007 . The tilts of the high bank were measured by two borehole tiltmeters. The connection between tilt values and the river- and groundwater-level variations was investigated by multivariable and moving window regression analyses on the basis of a 6-year-long observation from 2011 to 2016. The results show that increasing regression coefficients mean decreasing stability of the high river bank, so the developed method can be used for continuous supervision of the high bank stability. The method is also suitable for studying the causes of motion processes. Investigations showed clearly that the effect of groundwater table variations is two orders of magnitude higher than the water-level variations of the River Danube. In addition to the erosion of the river, various small tilts of the stable and unstable parts also contribute to the arising of new cracks in the stable part, decreasing its width.

Keywords: groundwater, high bank, landslide, river water, regression analysis, tilt

\footnotetext{
*Corresponding address: Geodetic and Geophysical Institute, Research Centre for Astronomy and Earth Sciences, Hungarian Academy of Sciences, Csatkai E. u. 6-8., H-9400 Sopron, Hungary

E-mail: Mentes.Gyula@csfk.mta.hu

This is an open-access article distributed under the terms of the Creative Commons Attribution-NonCommercial 4.0 International License, which permits unrestricted use, distribution, and reproduction in any medium for noncommercial purposes, provided the original author and source are credited, a link to the CC License is provided, and changes - if any - are indicated.
} 


\section{Introduction}

Landslides are recognized as a significant source of threat to human lives, property, and industrial objects, causing casualties and economic losses (Petley 2012). That is the reason for sustained efforts to study the effects that contribute to triggering landslides. In addition to the investigation of geologic, tectonic, and geometric properties of hillslopes, many authors have studied meteorological effects (e.g., Szabó 2003; Lollino et al. 2006; Mentes et al. 2014), particularly the effect of precipitation (Kirkby 1978; Iadanza et al. 2016), pore water pressure, soil moisture (e.g., Casagli et al. 1999; Rinaldi et al. 2004; Iverson 2005; Fox and Wilson 2010; Hencher 2010; Kim 2016; Amvrosiadi et al. 2017), soil erosion (e.g., Fox et al. 2007; Tian et al. 2017; Zhang et al. 2017), vegetation (Micheli and Kirchner 2002; Simon and Collison 2002; Marston 2010; Pollen-Bankhead and Simon 2010; Mentes and Bódis 2012), and groundwater- and river water-level variations (e.g., Schnellmann et al. 2010; Mentes 2017b) on river bank stability. However, to date, the direct effect of hydrological processes on movements and deformations of high river banks (e.g., Uchimura et al. 2010; Bittelli et al. 2012; Devoti et al. 2015; Mentes 2017a, 2017 b) were barely investigated. Since hydrological processes play a major role in development of landslides, the understanding of their role in determining the stability of high river banks is a significant research task for the development of early warning systems (e.g., Fathani et al. 2016; Intrieri and Gigli 2016; Greco and Pagano 2017; Wen et al. 2017).

The high, steep banks along the west side of the River Danube in Hungary are greatly prone to landslides (Schweitzer et al. 1978; Kleb and Schweitzer 2001). Figure 1 (left lower corner) shows the locations where disastrous landslides have occurred previously. On these areas, traditional hydrological, geologic, and geomechanical investigations were carried out (e.g., Domján 1952; Kézdi 1970; Pécsi 1971; Karácsonyi and Scheuer 1972; Horváth and Scheuer 1976; Moyzes and Scheuer 1978; Pécsi et al. 1979; Scheuer 1979; Szabó 2001; Mentes et al. 2009), but the relationships between movements of the high bank and processes such as geophysical, hydrological, and meteorological were not studied. In 2007, small movements commenced on the high loess bank of the River Danube in Dunaszekcső (Fig. 1, left lower corner). In August 2007, two borehole tiltmeters were installed on the high bank for continuous recording of tilts of the high bank, in addition to a geodetic network for Global Positioning System (GPS), electronic distance measurement, and precise leveling (Újvári et al. 2009). Since geodetic measurements could only be used for the determination of the yearly change of the geometry (topography) of the high river bank (Bugya et al. 2011; Mentes et al. 2012; Bányai et al. 2014), the continuous recording tiltmeters enable the study of the relationships between meteorological and hydrological processes and the high bank tilts (e.g., García et al. 2010; Bódis and Mentes 2012; Mentes and Bódis 2012). In this study, the effect of the interaction between the Danube's water level and groundwater level on the movements of the high river bank is investigated for the development of an early warning system. 


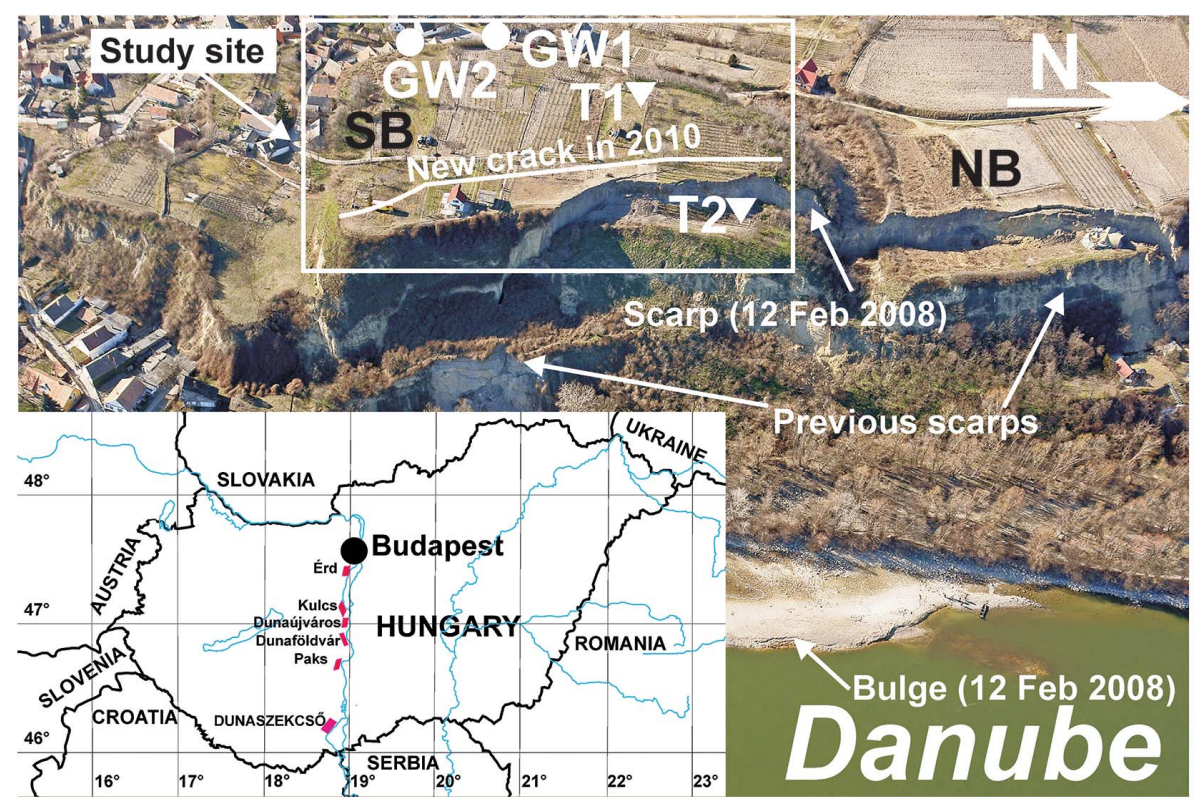

Fig. 1

Locations of landslides along the River Danube in Hungary (left lower corner) and the oblique aerial view (source: László Körmendy) of the high loess bank in Dunaszekcsö. T1 and T2 denote the borehole tiltmeters on the stable and unstable part of the high bank, respectively. GW1 and GW2 show the locations of the groundwater table sensors. White line denotes the crack that appeared in 2010

\section{Geologic setting}

According to published data, there was a large landslide of the high bank in Dunaszekcső in 1862, followed by small movements. The next large movements occurred in 1965 and 1976 (Kraft 2011). The traces of the previous slumps can also be seen in Fig. 1. From 2007 on, the movements of the high bank accelerated again and on February 12, 2008, one of the dangerous landslides occurred here.

Figure 1 shows the location (left lower corner) and the oblique aerial view of the high bank. The height of the investigated high loess bank is $142 \mathrm{~m}$ above the Baltic Sea level. The basement of the high bank consists of Triassic-Jurassic limestone located at 200-250 m below the surface; it is overlain with clayey and sandy sediments formed in the Upper Miocene and Pliocene. Above these layers, the uppermost $70 \mathrm{~m}$ of sedimentary sequence consists of sandy and clayey loess layers with brown to red fossil soils accumulated during the Pleistocene (Fig. 2). The high bank consists of a 20- to 30-m-high vertical loess wall above the 10 - to 20 -m-high slopes that consist of reworked loess from past landslides and fluvial mud, sand, and gravel deposits of the Danube (Szederkényi 1964; Urbancsek 1977; Kaszás and Kraft 2009; Kraft 2011). The younger loess series on top is much more prone to collapse 


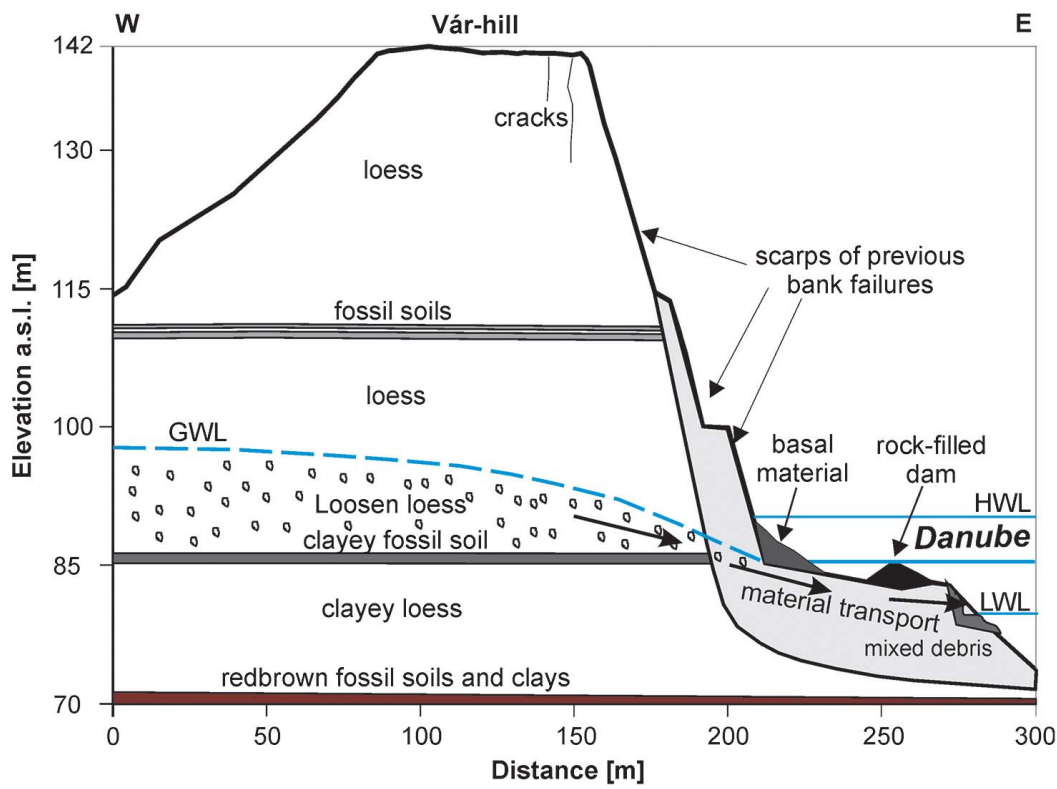

Fig. 2

Cross-section and geologic structure of the high bank at Dunaszekcső (after Kaszás and Kraft 2009; Újvári et al. 2009; Kraft 2011). a.s.1.: above Baltic Sea level; GWL: groundwater level; HWL: highest water level; LWL: lowest water level; E: east; W: west

(Moyzes and Scheuer 1978; Scheuer 1979); while the density of the younger loess deposits is about $1.6 \mathrm{~g} / \mathrm{cm}^{3}$ than that of the older loess series, and the intercalated paleosols is between 2.0 and $2.1 \mathrm{~g} / \mathrm{cm}^{3}$, and that of the Pannonian clay and sand reach $2.16 \mathrm{~g} / \mathrm{cm}^{3}$ (Hegedűs et al. 2008; Újvári et al. 2009).

The geologic structure of the high bank and its surroundings is summarized by Újvári et al. (2009) in detail.

\section{Methods and data processing}

The tilt of the loess wall was measured by the highly stable and sensitive Model 722A borehole tiltmeters produced by Applied Geomechanics Inc. (2018). This instrument has a dual axis tilt sensor and a built-in temperature sensor for measurement of the borehole temperature. The resolution of the tilt and temperature sensors is $0.1 \mu \mathrm{rad}(0.1 \mu \mathrm{m} / \mathrm{m})$ and $0.1{ }^{\circ} \mathrm{C}$, respectively. Two tiltmeters were installed on the study area in 2007. One of the instruments (T1) was placed on the stable and the other instrument (T2) on the unstable part of the high loess wall, as shown in Fig. 1. The $+y$ component (T1N and $\mathrm{T} 2 \mathrm{~N}$ ) of the tiltmeters was directed to the north, parallel to the River Danube, and the $+x$ components (T1E and T2E) to the east, perpendicular to the 
river. The instruments are placed in boreholes at a depth of $2.5 \mathrm{~m}$, which ensures stable temperature for the tiltmeters. The installation of the instruments is described by Mentes et al. (2012) in detail. Since the dry loess is a soft rock according to the classification of the International Association of Engineering Geology (Moyzes and Scheuer 1978), it can be assumed that the tilt of the deeper layer of the loess wall is the same as that of the borehole.

Two groundwater table gauges were installed at locations GW1 (in October 2009) and GW2 (in March 2010). GW1 is located ca. $100 \mathrm{~m}$ west of the sliding block, whereas GW2 is approximately located $200 \mathrm{~m}$ south of GW1 at a slightly lower height (Fig. 1). Tilt and groundwater-level data were recorded hourly. The water-level data of the River Danube are measured relative to the zero point of the water gauge, which is at a height of $79.92 \mathrm{~m}$ above the Baltic Sea. This data has been downloaded from the accessible website of the Directorate of Water Management (www.vizugy.hu). Since only daily water-level data of the River Danube were available, the daily averages of hourly tilt and groundwater-level data were used for the investigations.

To obtain a quantitative insight into the effect of the ground and river water-level variations on the high bank tilts, and to develop an early warning system, the data series were subjected to moving window regression (MWR) and multivariable regression (MVR) analyses using the TSoft (Van Camp and Vauterin 2005) and the OriginPro 9.1 programs (http://www.originlab.com), respectively.

\section{Results and discussion}

Figure 3 shows the high bank tilts, the groundwater tables (GW1 and GW2), and the water-level variations of the River Danube (DWL) between January 1, 2011 and March 31, 2016. T1E and T1N are the east and north tilt components measured on the stable part, and T2E and T2N are the east and north tilt components measured on the unstable part of the high bank. Increasing tilt values mean eastward and northward tilt, whereas decreasing values mean westward and southward tilts. The stable part of the high bank tilted oscillating with amplitudes of 20-60 $\mu \mathrm{rad}$ in the south direction (T1N component). The east component (T1E) trends slowly to east with alternating tilts with amplitudes of 10-30 $\mu \mathrm{rad}$. The rate of tilts increased both in the south and the east directions in 2013 and from this time on, the tilt continued with decreased rate. The resulting tilt in both directions was less than $150 \mu \mathrm{rad}$, not a considerable amount, in the whole measuring period. The movement of the unstable part is characterized by high tilt rates both in the east and in the north. The rate of the tilts increased considerably in both directions from 2015 on. During the investigated period, the tilt of the unstable part was much higher than that of the stable part. The resulting tilt in both directions is in the order of 1,000 $\mu \mathrm{rad}$. Figure 4 shows the resultant tilt (tick arrow) of the stable (T1N vs. T1E) and the unstable part (T2N vs. T2E), respectively. The direction of the resultant tilt of the stable part is approximately southeast, the tilt direction of the unstable part is northeast (NE). It can be assumed that the shear stress 


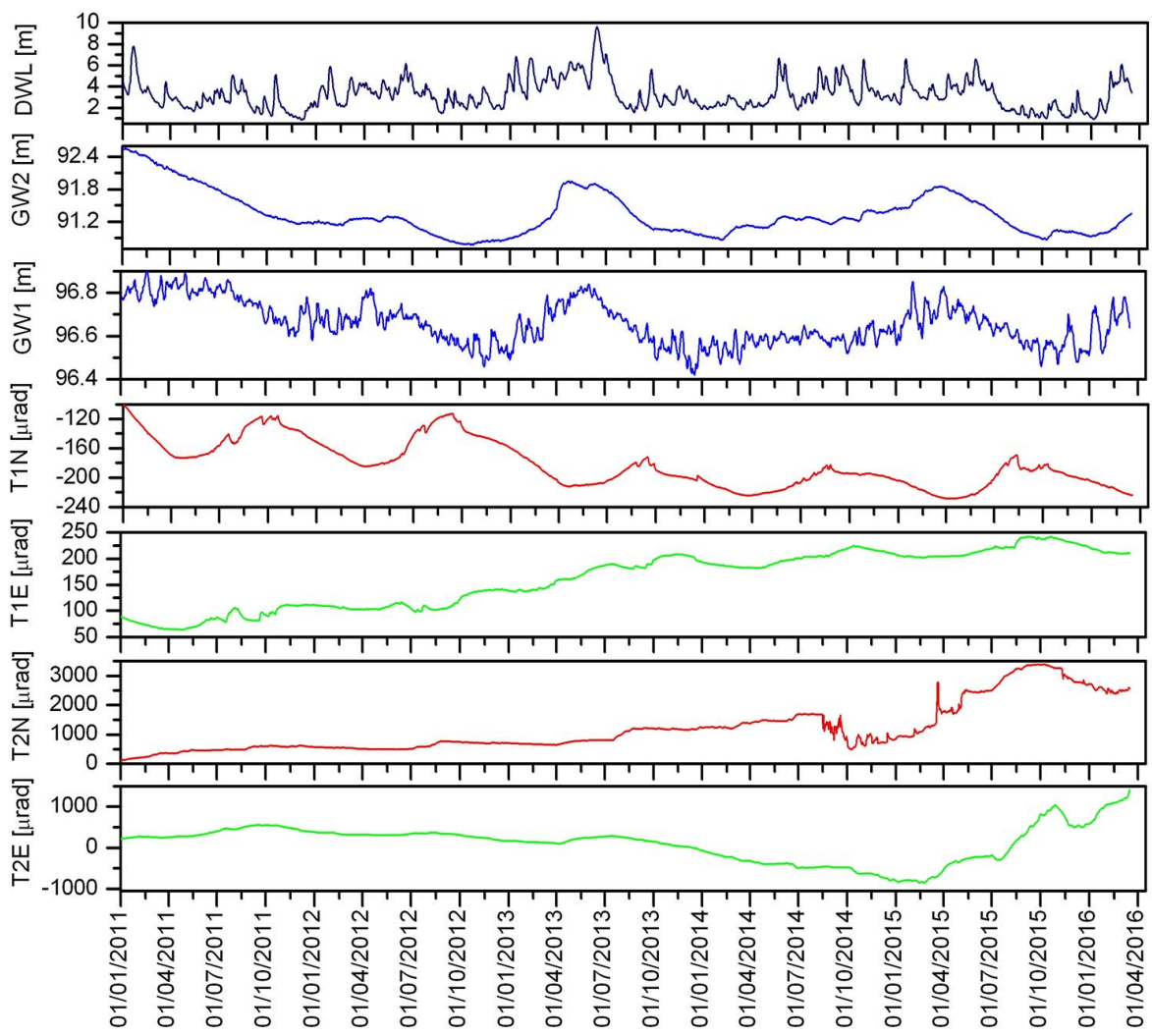

Fig. 3

Daily averaged data measured on the high loess bank in Dunaszekcső between January 1, 2011 and March 31, 2016. T1E and T1N are the east and north tilt components measured on the stable part of the high bank. T2E and $\mathrm{T} 2 \mathrm{~N}$ are the east and north tilt components measured on the unstable part of the high bank. Increasing tilt values represent eastward and northward tilt, while decreasing values represent westward and southward tilts. GW1 and GW2 denote the groundwater tables and DWL denotes the water level of the River Danube

between the stable and unstable parts of the high bank arising from the different motion of the two parts contributes to reducing the stability of the high bank, causing cracks in places where the shear stress exceeds cohesion. Since the movements caused by tilts of the unstable parts are larger than that of the stable part of the high bank, assuming a rigid loess wall, the cracks first appear on the top to a depth of some meters (see also Rinaldi and Casagli 1999). Geophysical measurements carried out by the pressure probe method (Szalai et al. 2014a) and electrical resistivity tomography (Szalai et al. 2014b) prove the presence of visible and invisible surface and nearsurface cracks with a depth of 1-10 m. These surface cracks promote penetration and seep of precipitation into the loess wall, thereby weakening the cohesion and further reducing the stability of the high bank (e.g., Midgley et al. 2013; Mulas et al. 2016). 

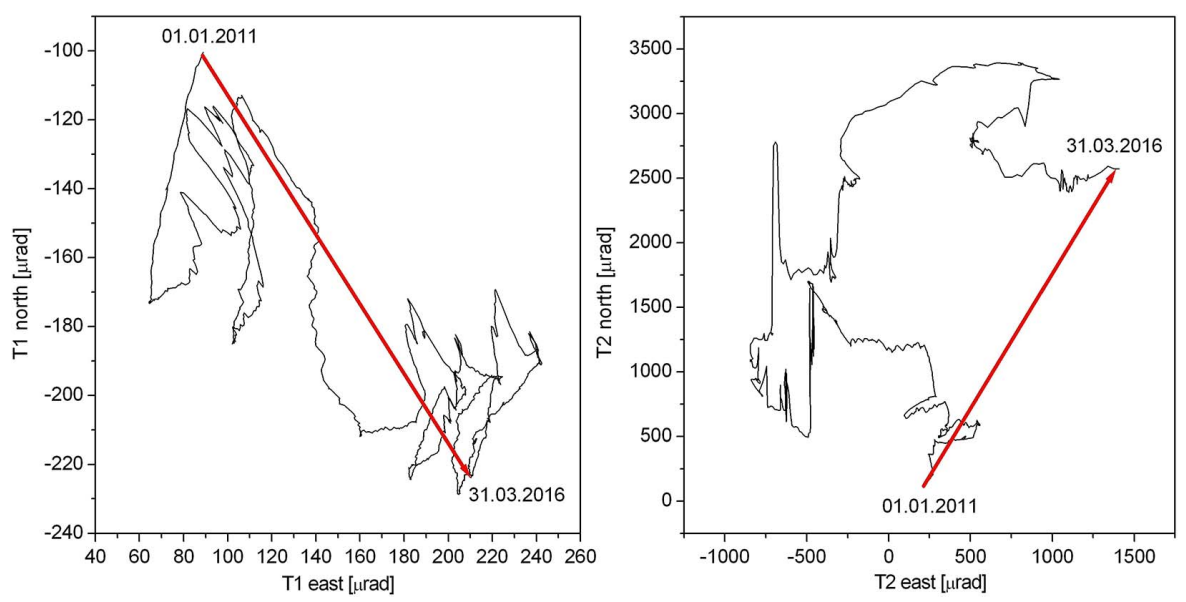

Fig. 4

Tilt variation of the stable (left) and the unstable (right) part of the high bank between January 1, 2011 and March 31, 2016. The thick arrows show the total tilts during the observation period

The River Danube is washing away the north part of the unstable section of the high bank more intensively than the south part; the undermining causes the long-term NE tilt of the unstable part. The subsiding masses of the unstable part of the high bank push the material simultaneously into the river and back into the loose base of the stable high bank, which is soaked through with groundwater and the river (Fig. 2). The recurring sinking of the unstable masses and the continuous transfer of the base material into the river cause the alternating east-west tilt of the high bank (Fig. 4). This vertically moving process can be seen in Fig. 5. The houses are vertical on the moving part of the high bank during the subsidence.

Table 1 shows the results of the MVR analysis. Regression coefficients (caused tilt per water level change of $1 \mathrm{~m}$ ) between each tilt component and the water levels were

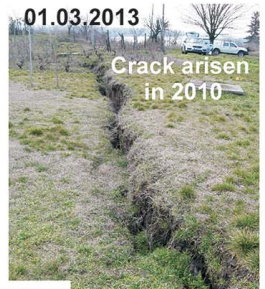

(a)
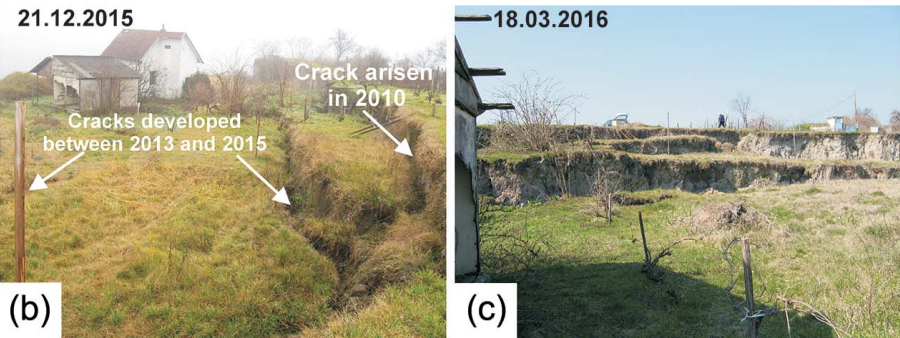

Fig. 5

Appearance and development of new cracks within the study site between 2010 and 2016 (photos were captured by the author) 
Table 1

Regression coefficients between tilt data and the water level of the River Danube (DWL), and the groundwater levels (GW1 and GW2) obtained by MVR analysis

\begin{tabular}{|c|c|c|c|c|c|}
\hline Tilt & Year & $\begin{array}{c}\text { GW1 } \\
(\mu \mathrm{rad} / \mathrm{m})\end{array}$ & $\begin{array}{c}\text { GW2 } \\
(\mu \mathrm{rad} / \mathrm{m})\end{array}$ & $\begin{array}{c}\text { DWL } \\
(\mu \mathrm{rad} / \mathrm{m})\end{array}$ & $R^{2}$ \\
\hline \multirow[t]{6}{*}{ T1E } & 2011 & -13 & -35 & 4 & 0.800 \\
\hline & 2012 & -41 & -44 & 3 & 0.658 \\
\hline & 2013 & -207 & 33 & -2 & 0.484 \\
\hline & 2014 & -23 & 63 & 2 & 0.533 \\
\hline & 2015 & 2 & -37 & -1 & 0.862 \\
\hline & 2016 & 13 & 13 & -1 & 0.789 \\
\hline \multirow[t]{6}{*}{$\mathrm{T} 1 \mathrm{~N}$} & 2011 & -193 & 3 & 7 & 0.388 \\
\hline & 2012 & 28 & -98 & -1 & 0.793 \\
\hline & 2013 & 67 & -56 & 1 & 0.619 \\
\hline & 2014 & 0 & 28 & 2 & 0.335 \\
\hline & 2015 & 28 & -44 & -2 & 0.775 \\
\hline & 2016 & 6 & -38 & -1 & 0.970 \\
\hline \multirow[t]{6}{*}{$\mathrm{T} 2 \mathrm{E}$} & 2011 & -400 & -178 & 18 & 0.862 \\
\hline & 2012 & 167 & 95 & -8 & 0.373 \\
\hline & 2013 & 369 & -83 & 11 & 0.733 \\
\hline & 2014 & -156 & $-1,095$ & 15 & 0.859 \\
\hline & 2015 & 334 & $-2,430$ & 40 & 0.800 \\
\hline & 2016 & -712 & 1,073 & 53 & 0.859 \\
\hline \multirow[t]{6}{*}{$\mathrm{T} 2 \mathrm{~N}$} & 2011 & 185 & -287 & -16 & 0.965 \\
\hline & 2012 & 33 & -512 & -6 & 0.933 \\
\hline & 2013 & $-1,380$ & -71 & -30 & 0.690 \\
\hline & 2014 & 776 & $-1,198$ & -22 & 0.531 \\
\hline & 2015 & 25 & 1,246 & -208 & 0.272 \\
\hline & 2016 & -199 & 114 & -36 & 0.389 \\
\hline
\end{tabular}

T1E, T1N and T2E, T2N denote the east and north tilt components measured on the top (stable part) and on the unstable (sliding) part of the high bank, respectively. The positive values denote tilts in the east and north and the negative values in the west and south directions. Regression coefficients mean the tilts in $\mu$ rad caused by a water-level change of $1 \mathrm{~m} . R^{2}$ is the $R$ square of the adjustment. MVR: multivariable regression 
calculated separately for each year to investigate the changes of the regression coefficients due to stability changes of the high bank. At first glance, it can be observed that the effect of the groundwater is at least 1-2 orders of magnitude higher than that of the Danube water level (DWL). The changing signs (plus sign of the regression coefficients represents that increasing water level tilts the high bank in north and east direction, while the minus sign represents tilts in the opposite direction) of the regression coefficients can be explained by the different stability state of the high bank and with the interaction between the groundwater level and the water level of the river. This latter is especially obvious in the case of the east tilt component of the unstable block (T2E), where regression coefficients between T2E-GW2 and T2E-DWL have opposite signs. This means that the increasing water level of the River Danube hinders by its hydrostatic pressure - groundwater flow into the river (Fig. 2). The higher the

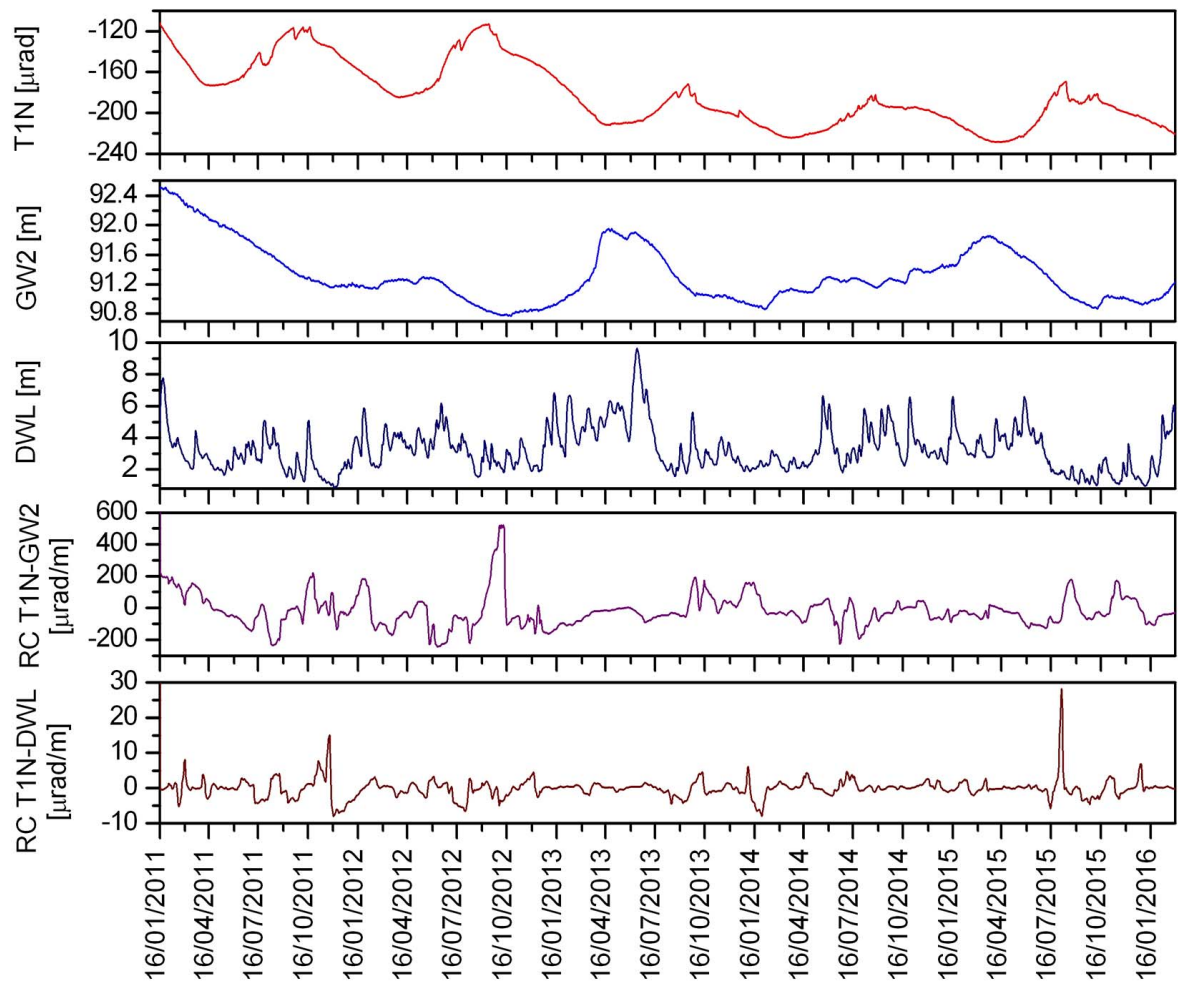

Fig. 6

MWR coefficient (RC) between the north tilt component (T1N) of the stable part of the high bank and the groundwater (GW2) level (RC T1N-GW2) and between the T1N and the water level (DWL) of the River Danube (RC T1N-DWL). T1N tilt curve moving in the positive direction means northward tilt, whereas moving in the negative direction means southward tilt 


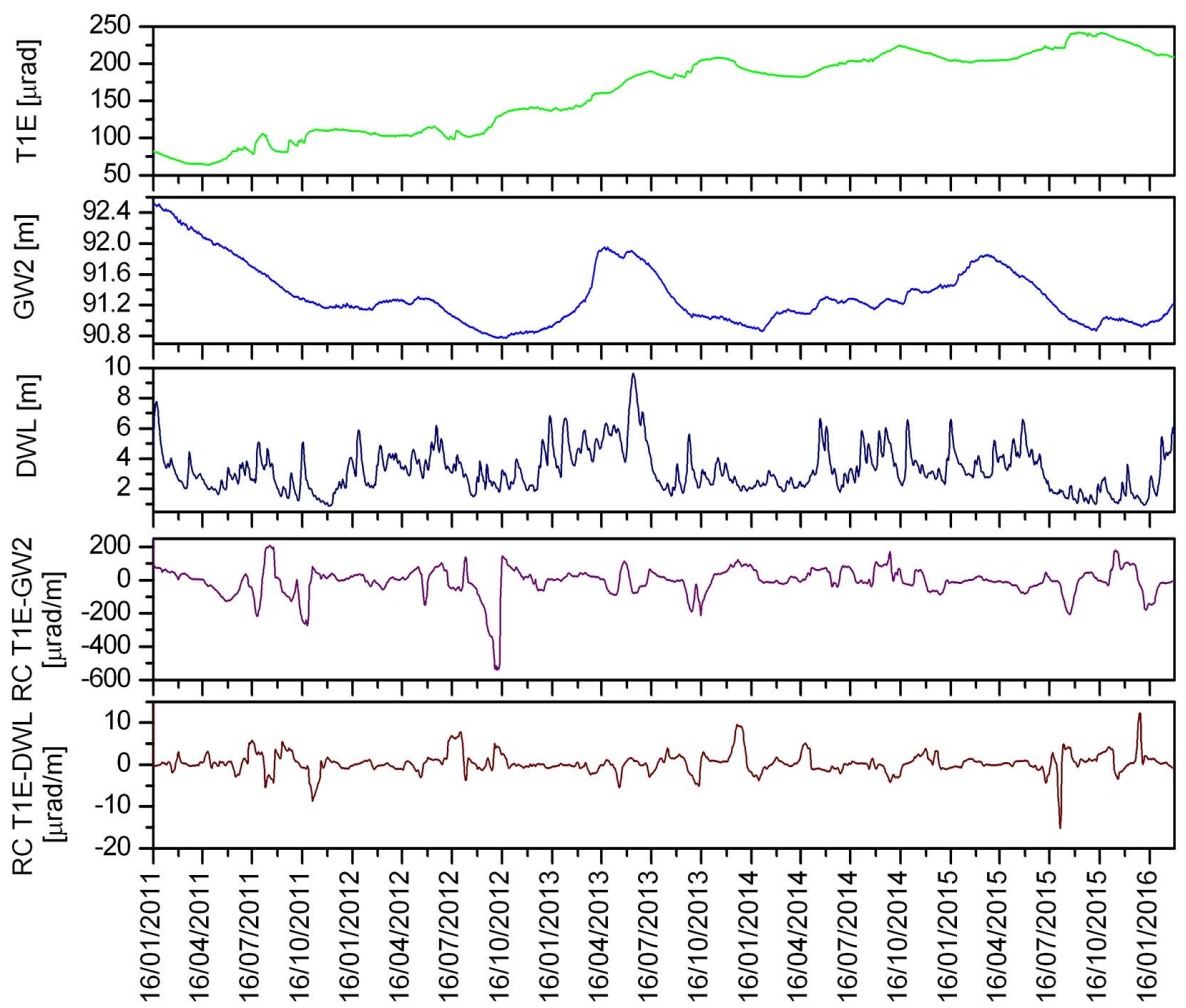

Fig. 7

MWR coefficient (RC) between the east tilt component (T1E) of the stable part of the high bank and the groundwater (GW2) level (RC T1E-GW2) and between the T1E and the water level (DWL) of the River Danube (RC T1E-DWL). T1E tilt curve moving in the positive direction means eastward tilt, whereas moving in the negative direction means westward tilt

regression coefficients (the higher the tilts caused by $1 \mathrm{~m}$ of water-level change), the lower the stability of the high bank. This fact can be used to predict a possible landslide due to stability loss of the high bank.

The first new crack after the large slump in 2008 (Újvári et al. 2009) appeared in the fall of 2010 (Fig. 1). The high regression coefficients between the tilts of the unstable part (T2E and T2N) and the water levels (GW2 and DWL) are distinct, showing the increased instability of the high bank. In 2014 and 2015, the regression coefficients (T2N-GW2) are much higher than before, as the new moving block arisen in 2010 (Fig. 5a) cracked into smaller blocks that were moving independently of each other (Fig. 5b). In 2015 and 2016, these subblocks subsided differently between 0.5 and $2.5 \mathrm{~m}$ (Fig. 5c). 


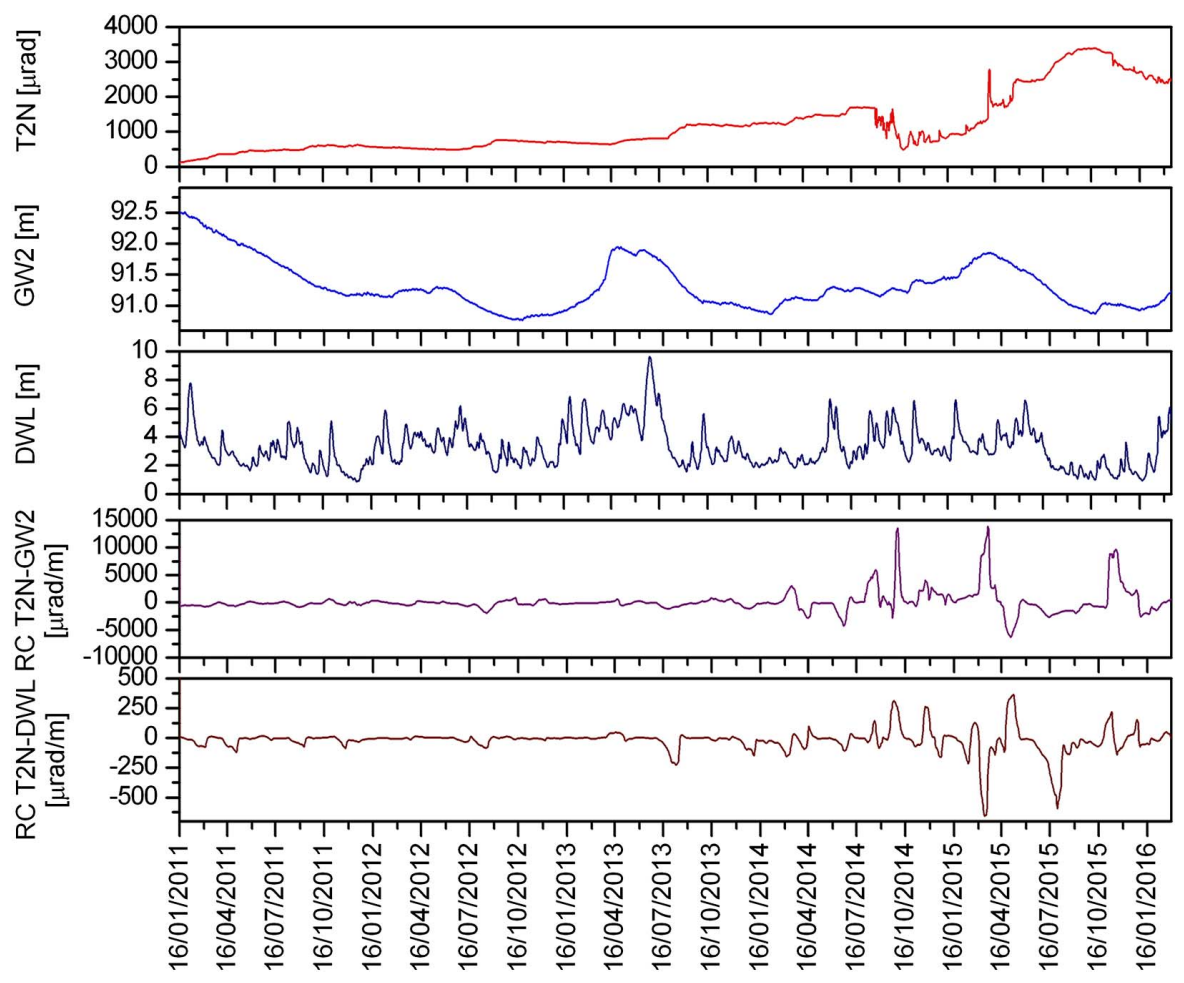

Fig. 8

MWR coefficient (RC) between the north tilt component (T2N) of the unstable part of the high bank and the groundwater (GW2) level (RC T2N-GW2) and between the T2N and the water level (DWL) of the River Danube (RC T2N-DWL). T2N tilt curve moving in the positive direction means northward tilt, whereas moving in the negative direction means southward tilt

MWR analysis with a window width of 30 days and a window shift of 1 day was used for continuous observation of the changing regression coefficients. Each tilt component was separately involved into the regression analysis with the groundwater level (GW2) and the water level of the Danube (DWL). The results can be seen in Figs 6-9. Figure 6 shows the north tilt of the stable part of the high bank. It can be seen that when both the groundwater level (GW2) and the DWL are high, the regression coefficients (RC T1N-GW2 and RC T1N-DWL) are small, which means that the hydrostatic pressures are balancing each other and that the tilt rate of the stable part decreases.

Figure 7 shows well the interaction of the groundwater and the water of the river. When the groundwater is very low, the stable part tilts westward (see, e.g., RC T1EGW2 in October 2012) and simultaneously the change of the DWL causes a small eastward tilt, slightly influencing the rate of the eastward tilt of the stable part. In July 


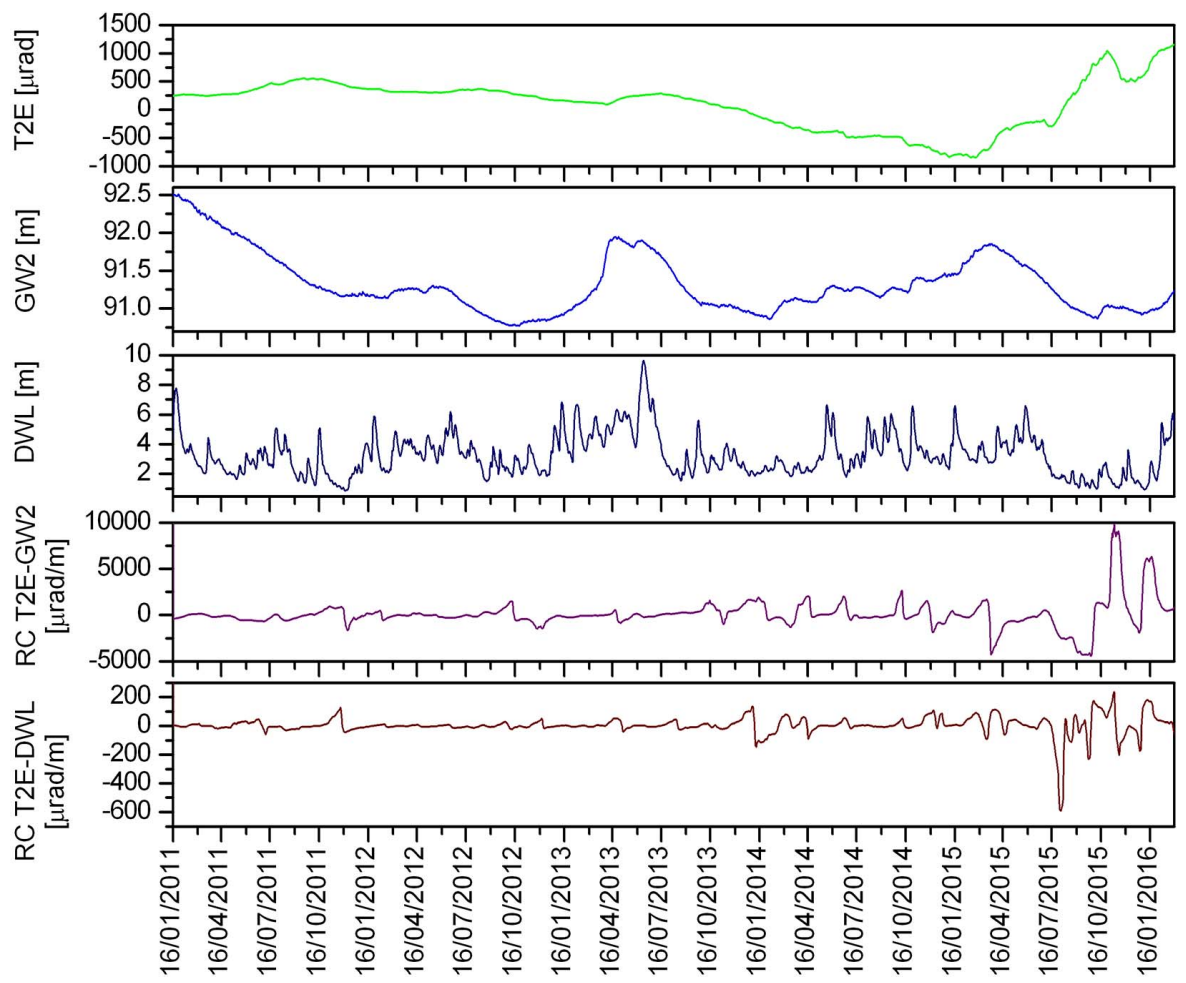

Fig. 9

MWR coefficient (RC) between the east tilt component (T2E) of the unstable part of the high bank and the groundwater (GW2) level (RC T2E-GW2) and between the T2E and the water level (DWL) of the River Danube (RC T2E-DWL). T2E tilt curve moving in the positive direction means eastward tilt, whereas moving in the negative direction means westward tilt

2015, both the GW2 and DWL influenced a westward tilt, but the effect of the groundwater (RC T1E-GW2 is -200) is much stronger then the effect of the river level (RC T1N-DWL is -16). Neither effect changed the eastward tilt of the stable part of the high bank. The tilt rate became only zero for a short period. In 2014, the stability of the unstable part began to decrease, especially the northward tilt increased and in 2015 its westward tilt changed to eastward tilt with an increasing rate. The water-level variation of the Danube can only modify the tilt rate, and sometimes the tilt direction, for a short time (Figs 8 and 9). The results show that the water-level fluctuations of the river do not directly trigger landslides (see also Scheuer 1979; Szabó 2003), as was previously believed that a rapid drawdown following a high river stage causes landslides (e.g., Horváth and Scheuer 1976). On the contrary, the river's role is twofold: on the one hand, especially during high water level, the river increases the 
moisture content, i.e., the pore water pressure, and loosens the basal material, thereby reducing the stability of the high bank. On the other hand, it erodes and undercuts the high bank (e.g., Rinaldi and Casagli 1999; Rinaldi et al. 2004; Fox et al. 2007; Fox and Wilson 2010). This process widens the unstable part and causes the retreating of the stable part of the high bank, which is proved by the appearance of new cracks from time to time. Since the subsidence of the stable part of the high bank is below the resolution of the GPS measurements (Bányai et al. 2014), the groundwater only transfers the base material of the unstable part to the river.

According to the previous investigations, the direct effect of the precipitation can be disregarded (Mentes and Bódis 2012; Mentes 2017a). Precipitation influences the groundwater level and the river stage and by this means indirectly, the movements of the high bank.

\section{Conclusions}

Using the developed method, the moving processes of the river banks can be well studied by borehole tiltmeters and the repeated and expensive geophysical and geodetic measurements for the stability control of the river banks can be performed less frequently or omitted.

The used methodology proved successful in highlighting and quantifying the interaction between groundwater- and river water-level variations, which play critical role in slope stability.

The results show that the effect of the groundwater-level variations on the high bank movements is about two orders of magnitude greater than that of the river.

The major roles of the river are to increase moisture and thereby to loosen the base material, to erode and undercut the high bank, and to continuously wash away the material transferred to the river from the base of the unstable part of the high river bank by the groundwater and thereby increase the width of unstable part.

Simultaneous tilt measurements on the stable and unstable parts of the high bank showed that the different tilt amplitudes and directions of the stable and unstable parts contribute to the arising of new cracks, decreasing the width of the stable part. Precipitation can flow into these cracks, decreasing the cohesive force.

Continuous moving window regression analysis between the online measured tilt and water-level data allows the remote sensing of the up-to-date stability of the high bank without the need for expensive geodetic or geophysical measurements on the high bank. Increasing regression coefficients represent decreasing stability. The method can be adapted to any active river bank to observe slope stability variations and to take the necessary measures for mitigation of damages in case of a possible landslide due to stability loss; thus, it can be used as a landslide early warning system or part of an early warning system. 


\section{Acknowledgements}

This research was supported by the Hungarian Scientific Research Fund under project OTKA K 81295. The author is much grateful for the technical assistance from the local government and János Kraft for his assistance in the investigation of the sliding processes of the high bank. He would also like to thank Tibor Molnár for his careful maintenance of the instruments, drilling boreholes, battery changes, and reading the data out.

\section{References}

Amvrosiadi, N., K. Bishop, J. Seibert 2017: Soil moisture storage estimation based on steady vertical fluxes under equilibrium. - Journal of Hydrology, 553, pp. 798-804.

Applied Geomechanics Inc. 2018: User's Manual: Model 722 Borehole Tiltmeter. - www.ampere.com.mx/ pdf/Manual_Usuario_Inc_722.pdf.

Bányai, L., Gy. Mentes, G. Újvári, M. Kovács, Z. Czap, K. Gribovszki, G. Papp 2014: Recurrent landsliding of a high bank at Dunaszekcső, Hungary: Geodetic deformation monitoring and finite element modeling. Geomorphology, 210, pp. 1-13.

Bittelli, M., R. Valentino, F. Salvatorelli, P.R. Pisa 2012: Monitoring soil-water and displacement conditions leading to landslide occurrence in partially saturated clays. - Geomorphology, 173, pp. 161-173.

Bódis, V.B., Gy. Mentes 2012: The role of vegetation in the daily and yearly small tilt variations of the Danube's high bank, Hungary. - Zeitschrift für Geomorphologie, 56/Suppl. 2, pp. 131-141.

Bugya, T., Sz.Á. Fábián, N.L. Görcs, I.P. Kovács, B. Radvánszky 2011: Surface changes on a landslide affected high bluff in Dunaszekcsö (Hungary). - Central European Journal of Geosciences, $3 / 2$, pp. 119-128.

Casagli, N., M. Rinaldi, A. Gargini, A. Curini 1999: Pore water pressure and streambank stability: Results from a monitoring site on the Sieve River, Italy. - Earth Surface Processes and Landforms, 24, pp. 1095-1114.

Devoti, R., D. Zuliani, C. Braitenberg, P. Fabris, B. Grillo 2015: Hydrologically induced slope deformations detected by GPS and clinometric surveys in the Cansiglio Plateau, southern Alps. - Earth and Planetary Science Letters, 419, pp. 134-142.

Domján, J. 1952: Középdunai magaspartok csúszásai [Slides of the bluffs along the middle reach of the River Danube]. - Hidrológiai Közlöny, 32, pp. 416-422. (in Hungarian)

Fathani, T.F., D. Karnawati, W. Wilopo 2016: An integrated methodology to develop a standard for landslide early warning systems. - Natural Hazards and Earth System Sciences, 16, pp. 2123-2135.

Fox, G.A., G.V. Wilson 2010: The role of subsurface flow in hillslope and stream bank erosion: A review. Soil Science Society of America Journal, 74, pp. 717-733.

Fox, G.A., G.V. Wilson, A. Simon, E.J. Langendoen, O. Akay, J.W. Fuchs 2007: Measuring streambank erosion due to ground water seepage: Correlation to bank pore water pressure, precipitation and stream stage. - Earth Surface Processes and Landforms, 32, pp. 1558-1573.

García, A., A. Hördt, M. Fabian 2010: Landslide monitoring with high resolution tilt measurements at the Dollendorfer Hardt landslide, Germany. - Geomorphology, 120, pp. 16-25.

Greco, R., L. Pagano 2017: Basic features of the predictive tools of early warning systems for water-related natural hazards: Examples for shallow landslides. - Natural Hazards and Earth System Sciences, 17, pp. 2213-2227.

Hegedűs, E., A.Cs. Kovács, T. Fancsik 2008: A megcsúszott dunaszekcsői löszfal aktív és passzív szeizmikus vizsgálata [Active and passive seismic investigation of the slipped loess bluff at Dunaszekcsö]. - Research Report of the Eötvös Lóránd Geophysical Institute, Budapest, 20 p. (in Hungarian) 
Hencher, S.R. 2010: Preferential flow paths through soil and rock and their association with landslides. Hydrological Processes, 24, pp. 1610-1630.

Horváth, Zs., Gy. Scheuer 1976: A dunaföldvári partrogyás mérnökgeológiai vizsgálata [Engineeringgeological investigation of the river bank slide of Dunaföldvár]. - Földtani Közlöny, 106, pp. 425-440. (in Hungarian)

Iadanza, C., A. Trigila, F. Napolitano 2016: Identification and characterization of rainfall events responsible for triggering of debris flows and shallow landslides. - Journal of Hydrology, 541/A, pp. 230-245.

Intrieri, E., G. Gigli 2016: Landslide forecasting and factors influencing predictability. - Natural Hazards and Earth System Sciences, 16, pp. 2501-2510.

Iverson, R.M. 2005: Regulation of landslide motion by dilatancy and pore pressure feedback. - Journal of Geophysical Research, 110/F2, F02015.

Karácsonyi, S., Gy. Scheuer 1972: A dunai magaspartok vízföldtani sajátosságai [Hydrogeological properties of high banks along the Danube]. - Hidrológiai Közlöny, 9, pp. 375-383. (in Hungarian)

Kaszás, F., J. Kraft 2009: A dunaszekcsői magaspart rogyásos suvadása [Collapsing landslide of the Danube's high bank in Dunaszekcső]. - Mélyépítő Tükörkép Magazin, 2, pp. 35-39. (in Hungarian)

Kézdi, Á. 1970: A dunaújvárosi partrogyás [The bank collapse at Dunaújváros]. - Mélyépítéstudományi Szemle, 20, pp. 281-297. (in Hungarian)

Kim, S. 2016: Time series modeling of soil moisture dynamics on a steep mountainous hillside. - Journal of Hydrology, 536, pp. 37-49.

Kirkby, M.J. 1978: The replacement of rainwater in the soil on the hillside. - Hillslope Hydrology, 2, pp. 18-24.

Kleb, B., F. Schweitzer 2001: A Duna csuszamlásveszélyes magaspartjainak településkörnyezeti hatásvizsgálata [Assessment of the impact of landslide prone high banks on urban environment along the River Danube]. - In: Ádám, A., A. Meskó (Eds): Földtudományok és a földi folyamatok kockázati tényezöi [Earth sciences and risk factors for terrestrial processes]. Hungarian Academy of Sciences, Budapest, pp. 169-193. (in Hungarian)

Kraft, J. 2011: Dunai magaspart dunaszekcsői részletének rogyásos suvadásai [Collapsing landslide of the Danube's high bank in Dunaszekcső]. - Mérnökgeológia-Kőzetmechanika, 2011, pp. 93-104. (in Hungarian)

Lollino, G., M. Arattano, P. Allasia, D. Giordan 2006: Time response of a landslide to meteorological events. - Natural Hazards and Earth System Sciences, 6, pp. 179-184.

Marston, R.A. 2010: Geomorphology and vegetation on Mountain slopes: Interactions, dependencies, and feedback loops. - Geomorphology, 116, pp. 206-217.

Mentes, Gy. 2017a: The role of recent tectonics and hydrological processes in the evolution of recurring landslides on the Danube's high bank in Dunaföldvár Hungary. - Geomorphology, 290, pp. 200-210.

Mentes, Gy. 2017b: Observing slope stability changes on the basis of tilt and hydrologic measurements. Journal of Applied Geodesy, 11/2, pp. 115-121.

Mentes, Gy., L. Bányai, G. Újvári, G. Papp, K. Gribovszki, B.V. Bódis 2012: Recurring mass movements on the Danube's bank at Dunaszekcső (Hungary) observed by geodetic methods. - Journal of Applied Geodesy, 6/3-4, pp. 203-208.

Mentes, Gy., V.B. Bódis 2012: Relationships between short periodic slope tilt variations and vital processes of the vegetation. - Journal of Applied Geodesy, 6/2, pp. 83-88.

Mentes, Gy., V.B. Bódis, P. Vig 2014: Small slope tilts caused by meteorological effects and vital processes of trees on a wooded slope in Hidegvíz Valley, Hungary. - Geomorphology, 206, pp. 239-249.

Mentes, Gy., B. Theilen-Willige, G. Papp, F. Síkhegyi, G. Újvári 2009: Investigation of the relationship between subsurface structures and mass movements of the high loess bank along the River Danube in Hungary. - Journal of Geodynamics, 47, pp. 130-141.

Micheli, E.R., J.W. Kirchner 2002: Effects of meadow riparian vegetation on streambank erosion. 2: Measurements of vegetated bank strength and consequences for failure mechanics. - Earth Surface Processes and Landforms, 27, pp. 687-697.

Midgley, T.L., G.A. Fox, G.V. Wilson, D.M. Heeren, E.J. Langendoen, A. Simon 2013: Seepage-induced streambank erosion and instability: In situ constant-head experiments. - Journal of Hydrologic Engineering, 18/10, pp. 1200-1210. 
Moyzes, A., Gy. Scheuer 1978: A dunaszekcsői magaspart mérnökgeológiai vizsgálata [Engineering geological investigation of the high bank at Dunaszekcső]. - Földtani Közlöny, 108, pp. 213-226. (in Hungarian)

Mulas, M., J. Corominas, A. Corsini, J. Moya 2016: Analysis of slope processes in the Vallcebre landslide (Eastern Pyrenees, Spain) by means of Cross Correlation Function applied to high frequency monitoring data. - Natural Hazards and Earth System Sciences Discussions. https://www.nat-hazards-earth-syst-scidiscuss.net/nhess-2016-253/nhess-2016-253.pdf.

Pécsi, M. 1971: Az 1970. évi dunaföldvári földcsuszamlás [The Dunaföldvár landslide in 1970]. - Földrajzi Értesítő, 20, pp. 233-238. (in Hungarian)

Pécsi, M., F. Schweitzer, Gy. Scheuer 1979: Engineering geological and geomorphological investigations of landslides in the loess bluffs along the Danube in the Great Hungarian Plain. - Acta Geologica Hungarica, 22, pp. 327-343.

Petley, D. 2012: Global patterns of loss of life from landslides. - Geology, 40/10, pp. 927-930.

Pollen-Bankhead, N., A. Simon 2010: Hydrologic and hydraulic effects of riparian root networks on streambank stability: Is mechanical root-reinforcement the whole story? - Geomorphology, 116, pp. 353-362.

Rinaldi, M., N. Casagli 1999: Stability of streambanks formed in partially saturated soils and effects of negative pore water pressures: The Sieve River (Italy). - Geomorphology, 26, pp. 253-277.

Rinaldi, M., N. Casagli, S. Dapporto, A. Gargini 2004: Monitoring and modelling of pore water pressure changes and riverbank stability during flow events. - Earth Surface Processes and Landforms, 29 , pp. 237-254.

Scheuer, Gy. 1979: A dunai magaspartok mérnökgeológiai vizsgálata [Engineering geological investigation of the high banks of the Danube]. - Földtani Közlöny, 109, pp. 230-254. (in Hungarian)

Schnellmann, R., M. Busslinger, H.R. Schneider, H. Rahardjo 2010: Effect of rising water table in an unsaturated slope. - Engineering Geology, 114, pp. 71-83.

Schweitzer, F., Á. Juhász, J. Szilárd 1978: Magyarország felszínmozgásos területeinek földtani és müszaki katasztere [Geological and technological cadaster of the surface-motion areas of Hungary]. - Geological Institute of Hungary, Budapest, 22 p. (in Hungarian)

Simon, A., A.J.C. Collison 2002: Quantifying the mechanical and hydrological effects of riparian vegetation on streambank stability. - Earth Surface Processes and Landforms, 27/5, pp. 527-546.

Szabó, J. 2001: A csuszamlásos folyamatok szerepe a magyarországi felszínformák kialakulásában [Role of sliding processes in development of the Hungarian surface features]. - In: Ádám, A., A. Meskó (Eds): Földtudományok és a földi folyamatok kockázati tényezöi [Earth sciences and risk factors for terrestrial processes]. Hungarian Academy of Sciences, Budapest, pp. 143-168. (in Hungarian)

Szabó, J. 2003: The relationship between landslide activity and weather: Examples from Hungary. - Natural Hazards and Earth System Sciences, 3, pp. 43-52.

Szalai, S., K. Szokoli, M. Metwaly 2014a: Delineation of landslide endangered areas and mapping their fracture systems by the pressure probe method. - Landslides, 11, pp. 923-932.

Szalai, S., K. Szokoli, A. Novák, Á. Tóth, M. Metwaly, E. Prácser 2014b: Fracture network characterisation of a landslide by electrical resistivity tomography. - Natural Hazards and Earth System Sciences Discussions, 2, pp. 3965-4010.

Szederkényi, T. 1964: A baranyai Duna menti mezozoós szigetrögök földtani viszonyai [Geological conditions of the Mesozoic blocks along the River Danube in county Baranya]. - Földtani Közlöny, 94, pp. 27-32. (in Hungarian)

Tian, P., X. Xu, C. Pan, K. Hsu, T. Yang 2017: Impacts of rainfall and inflow on rill formation and erosion processes on steep hillslopes. - Journal of Hydrology, 548, pp. 24-39.

Uchimura, T., I. Towhata, T.T.L. Anh, J. Fukuda, C.J.B. Bautista, L. Wang, I. Seko, T. Uchida, A. Matsuoka, Y. Ito, Y. Onda, S. Iwagami, M.-S. Kim, N. Sakai 2010: Simple monitoring method for precaution of landslides watching tilting and water contents on slopes surface. - Landslides, 7, pp. 351-357.

Újvári, G., Gy. Mentes, L. Bányai, J. Kraft, A. Gyimóthy, J. Kovács 2009: Evolution of a bank failure along the River Danube at Dunaszekcső, Hungary. - Geomorphology, 109, pp. 197-209. 
Urbancsek, J. 1977: Magyarország mélyfúrású kútjainak katasztere VII [Cadastre of the Deep-Drilling Wells in Hungary VII]. - Vízgazdálkodási Intézet, Budapest, 546 p. (in Hungarian)

Van Camp, M., P. Vauterin 2005: Tsoft: Graphical and interactive software for the analysis of time series and earth tides. - Computers \& Geosciences, 31/5, pp. 631-640.

Wen, T., H. Tang, Y. Wang, C. Lin, C. Xiong 2017: Landslide displacement prediction using the GALSSVM model and time series analysis: A case study of Three Gorges Reservoir, China. - Natural Hazards and Earth System Sciences, 17, pp. 2181-2198.

Zhang, F.B., M.Y. Yang, B.B. Li, Z.B. Li, W.Y. Shi 2017: Effects of slope gradient on hydro-erosional processes on an aeolian sand-covered loess slope under simulated rainfall. - Journal of Hydrology, 553, pp. $447-456$. 